\title{
POLA PEMBENTUKAN KONSTRUKSI VERBA SERIAL DALAM BAHASA BATAK TOBA (TEORI $X$-BAR)
}

\author{
Elza Leyli Lisnora Saragih ${ }^{1}$, Mulyadi ${ }^{2}$ \\ Universitas Sumatera Utara, Medan, Indonesia ${ }^{1,2}$ \\ elzalisnora@gmail.com ${ }^{1}$, mulyadi.usu@gmail.com ${ }^{2}$
}

\begin{abstract}
This study aimed to describe the construction and how the formation pattern of serial verbs in Batak Toba language through X-bar theory. A qualitative descriptive method with data collection techniques using note-taking and interview techniques was used. Data were collected from interviews with native speakers and the text of Toba Batak language almanac. In analyzing the data, a method of distribution was employed. The results showed that the formation pattern of serial verbs in the Batak Toba language consisted of 4 types namely which were [transitive V1+ transitive V2], [transitive V1+intransitive V2], [intransitive V1+ transitive V2], and [intransitive V1 + intransitive V2]. The first type, [transitive V1+ transitive V2] is formed from the predicate that followed by the object + the predicate and followed by the object. The next formation, [V1 transitive $+\mathrm{V} 2$ intransitive] is formed from predicates followed by object + predicates and not followed by the object. The later type, [V1 intransitive $+\mathrm{V} 2$ transitive] is formed from predicates that not followed by object + predicates and followed by an object. Further, the last type, [intransitive $\mathrm{V} 1+\mathrm{V} 2]$ is formed from a predicate not followed by an object + a predicate and not followed by an object.
\end{abstract}

Keyword: constructions, serial verb, $x$-bar

\begin{abstract}
ABSTRAK
Bahasa Batak Toba merupakan bahasa yang memiliki keunikan bila dibandingkan dengan bahasa Proto Melayu lainnya. Kekhasan bahasa ini terletak pada konstruksi kalimatnya yang berpola VOS, dimana kata kerja selalu mendahulu Subjek. Dalam penelitian ini dibahas mengenai konstruksi verba serial dalam bahasa Batak Toba. Metode penelitian adalah deskripftif kualitatif dengan teknik pengumpulan data menggunakan teknik simak catat dan juga wawancara. Data dikumpulkan melalui wawancara tatap muka dengan penutur aslinya. Selanjutnya data dianalisis dengan menggunakan metode agih. Hasil penelitian menunjukkan bahwa pola pembentukan verba serial dalam bahasa Batak Toba terdiri atas empat pola yaitu [transitif V1+ transitif V2], [transitif V1+intransitif V2],[intransitif V1+ transitif V2], [intransitif V1 + intransitif V2]. Verba serial bertipe [transitif V1+ transitif V2] terbentuk dari predikat yang diikuti oleh objek + predikat yang diikuti oleh objek. Verba serial bertipe [V1 transitif + V2 intransitif] terbentuk dari predikat yang diikuti oleh objek + predikat yang tidak diikuti oleh objek. Verba serial bertipe [V1 intransitif + V2 transitif] terbentuk dari predikat yang tidak diikuti oleh objek + predikat yang diikuti oleh objek. Verba serial bertipe [V1 intransitif $+\mathrm{V} 2$ intranstif] terbentuk dari predikat yang tidak diikuti oleh objek + predikat yang tidak diikuti oleh objek.
\end{abstract}

Kata Kunci : konstruksi, verba serial, $x$-bar

\section{PENDAHULUAN}

Bahasa batak Toba merupakan salah satu bahasa daerah yang ada di wilayah Sumatera Utara. Bahasa ini merupakan salah satu rumpun cabang bahasa Proto Malaya. Penutur bahasa Batak Toba mayoritas tinggal di Daerah Tingkat II Kabupaten Tapanuli
Utara dan Kabupaten Toba Samosir. Adapun Kabupaten Tapanuli Utara memiliki luas 3793,31 kilometer persegi dengan jumlah populasi 293.399 jiwa dan Kabupaten Toba Samosir 2.021,80 kilometer persegi dengan jumlah populasi 180.69 kilometer persegi dengan jumlah populasi 180.694 jiwa. Saat ini

Pola Pembentukan Kontruksi Verba Serial dalam Bahasa Batak Toba (Teori X-Bar) 
penutur bahasa Batak Toba tidak hanya berada didua daerah tersebut melainkan sudah terseber ke wilayah lain, dengan jumlah penutur sekitar 4 juta jiwa.

Bahasa Batak Toba memiliki konstruksi kalimat yang berbeda dari bahasa Proto Malaya pada umumnya. Jika konstruksi kalimat pada umumnya berpola SVO, konstruksi kalimat dalam bahasa ini berpola VOS, di mana verba selalu mendahului subjek. (Sibarani, 1997) Kekhasan bahasa ini menarik diteliti. Untuk itu, dalam tulisan ini dibahas bagaimanakah konstruksi verba serial dalam bahasa Batak Toba. Hasil penelitian ini diharapkan dapat memberikan penggambaran yang rinci mengenai konstruksi verba serial.

Verba merupakan komponen utama dalam membentuk sebuah kalimat. Verba adalah bentuk yang mengungkapkan peristiwa. Sebagai suatu peristiwa maka verba mengimplikasikan suatu perubahan yang terjadi dalam waktu. Menurut Asnawi dan Mukhlis (2019) verba atau kata kerja merupakan kata-kata yang menyatakan suatu perbuatan atau tindakan, proses, gerak, keadaan atau terjadinya sesuatu. Jadi, jelas bahwa verba adalah kata yang mengindikasikan tindakan atau proses dan menjadi sentral dalam kalimat.

Verba dikelompokkan dalam dua golongan yaitu verba tunggal dan verba serial. Predikat verba tunggal adalah predikat dengan verba utama yang terdiri dari satu sedangkan predikat verba serial adalah predikat yang struktur predikatif dengan verba utamanya lebih dari satu. (Verhaar, 2001)

Verba serial atau disebut juga dengan serialisasi verba merupakan konstruksi predikatif yang bentuknya terdiri atas dua atau lebih verba inti dan keduanya muncul secara berdampingan dan keberadaannya cukup kuat dan mempunyai perilaku seperti verba tunggal atau bentuk verba sederhana. Bentuk Serialisasi verba ini terjadi saat dua atau lebih bentuk verba saling berdampingan dan kedua bentuk tersebut bertindak sebagai predikat tunggal. (Durie, 1997). Keberadaan bentuk ini dapat dilihat dari setidak-tidaknya terdapat dua kata kerja maupun pelengkap yang relevan dan jika memungkinkan dengan pembagian kata kerja yang hanya terdiri dari satu subjek tanpa adanya tanda koordinasi. Bentuk verba serial (serial verb) ini seringdibandingkan dengan predikat kompleks (complex predicate), karena keduanya memiliki konstruksi yang mirip. Untuk membedakannya dapat dilihat dari ciriciri konstruksi sintaksis,semantik dan fonologis.

Konstruksi sintaksis verba serial ditandai oleh ciri-ciri :1) dibentuk oleh sederetan unit verba selanjutnya 2) rentetan unit verba tidak menggunakan konjungsi, 3) urutan unit verba membentuk satu klausa dengan adanya persamaan argumen dan kategori fungsional. Secara semantik konstruksi verba serial biasanya menyatakan suatu kejadian kompleks yang terdiri atas dua atau lebih sub kejadian yang terjadi secara simultan dan berurutan secara dekat antara satu dengan yang lainnya. Selanjutnya secara fonologis rentetan unit verbal dan konstruksi verba serial membentuk unit intonasi yang sama. (Kroeger, 2004) bandingkan dengan (Aikhenvald. Y Alexandra, 2006) dan (Givon, 1984)

Berikut 10 generalisasi dalam konstruksi verba serial :

1. Semua KVS, kata kerja memiliki tense yang sama

2. Semua KVS, kata kerja memiliki mood yang sama

3. Kata kerja dalam KVS tidak memiliki bentuk yang terpisah atau lokasional pengubah

4. Semuan KVS diucapkan dengan kontur intonasi tunggal, seperti lausa kata kerja tunggal

5. Jika KVS menunjukkan hubungan sebab akibat, atau kejadian berurutan, urutan kedua kata kerja tersebut adalah penanda tense yaitu kata kerja sebab yang mendahului kata kerja akibat dan kata kerja yang mengungkapkan peristiwa sebelumnya mendahului kata kerja yang mengekspresikan peristiwa selanjutnya

6. Jika hanya terdapat satu satu mood atau penanda negasi, maka hal tersebut terjadi pada posisi pinggiran atau mengikuti kata kerja terakhir

7. Dalam semua KVS semua kata kerja berbagi setidaknya satu argumen 
8. Semua bahasa dengan KVS memiliki konstruksi kata kerja serial subjek yang sama, mungkin bersama dengan tipe lain

9. Dalam KVS subjek yang berbeda, kata kerja kedua selalu intransitif

10. KVS tidak dapat memiliki dua agen yang berbeda yaitu ketika non agen dibagikan, maka agen tersebut harus dibagikan juga.(Haspelmath, 2016).

Berdasarkan penjelasan di atas dapat siambil kesimpulan bahwa verba serial berbeda dengan predikat kompleks, sekalipun keduanya sama-sama dapat dibentuk secara merfologis dan sintaksis. Dalam konstruksi dan struktur predikat kompleks ditemukan konstruksi yang lebih dari satu predikat, dimana predikat yang satu menjadi argument pada predikat yang lainnya.. Berbeda halnya dalam konstruksi verba serial yang harus berpredikat tunggal. Keduanya dapat kita lihat pada contoh berikut :

(a) lao manikkir namate

pergi melihat yang meninggal

'pergi melihat orang yang meninggal'

(b) mardalan jala marlojong

mandapothon

ianakhonna

berjalan

kemudian

berlari

menghampiri

anaknya

'berjalan dan berlari menghampiri anaknya

Konstruksi laho manikkir merupakan verba serial dengan ciri tidak diapit oleh konjungsi dan bertindak sebagai predikat tunggal sedangkan konstruksi mardalan jala marlojong merupakan predikat kompleks.

Konstruksi verba serial (KVS) mempunyai ciri-ciri terbentuk dari sederetan verba yang tidak dihubungkan dengan pemarkah konjungsi. KVS menggambarkan suatu peristiwa tunggal, dan KVS berbagi argument yang sama dan masing-masing verba dapat berdiri sendiri dalam konstruksi bukan serial verba (Aikhenvald. Y Alexandra, 2006)

Dalam kajian ini peneliti menganalisis konstruksi verba serial dengan menggunakan teori $\mathrm{x}$-Bar. Teori ini dipakai pertama sekali oleh Noams Comsky yang digunakan secara universal dan dapat menganalisis bahasa- bahasa di dunia sekalipun susunannya berbeda-beda. Teori x-bar digunakan sebab bentuk kaidah kategori struktur frasa dan kaidah struktur sintaksis hanya dapat digunakan pada jenis proyeksi yang terbatas. Selain itu, jika kita kaji, kaidah struktur sintaksis dan kaidah struktur frasa terlalu luas sehingga perlu dibatasi sehingga lebih spesifik. Selanjutnya, teori ini diterapkan pada tataran frasa ( dengan simbol X") dan kategori antara , yakni kategori yang lebih besar dari kata , tetapi lebih kecil dari frasa (symbol X') yang menjadi dasar munculnya teori X-Bar.

Dalam teori $\mathrm{X} ;$ Bar terdapat dua tataran dan dua proyeksi yang direpresentasikan pada level kalimat. Apabila sebuah kategori leksikal dibetuk oleh sebuah komplemen, keterangan dan specifier makan komplemen yang berkombinasi dengan $\mathrm{X}$ akan membentuk proyeksi X-bar ; keterangan yang berkombinasi dengan x-bar akan membentuk proyeksi x-bar yang lebih tinggi ; spesifier yang berkombiansi dengan x-bar yang lebih tinggi akan membentuk frase impleksional sebagai proyeksi yang maksimal. Jadi, kategori bar adalah proyeksi dari $\mathrm{X}$ dengan frase bar tertinggi ialaha proyeksi maksimal dari kategori X (Mulyadi, 2010)

Berikut diagram pohonnya :

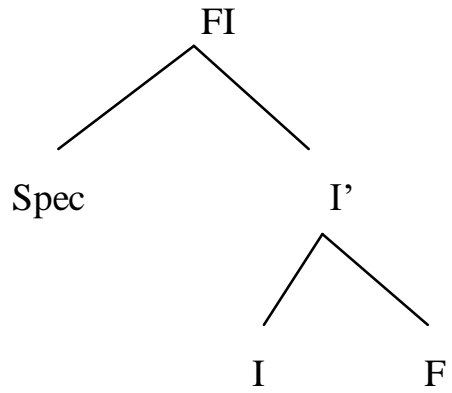

Dari diagram pohon di atas dapat dijelaskan FV (Frasa Verba ) yang berkontribusi dengan I ( Impleksi) membentuk I'. Kemudian I' dan specifier membentuk FI pada level kalimat. Hal ini juga dapat dilihat pada format umum di bawah ini:

$\mathrm{FI} \longrightarrow$ SPES; I'

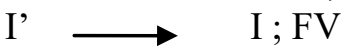

Pola Pembentukan Kontruksi Verba Serial dalam Bahasa Batak Toba (Teori X-Bar) 
Haegeman (1992) merepresentasikan teori $\mathrm{x}$-bar dengan diagram menggunakan pohon berikut :

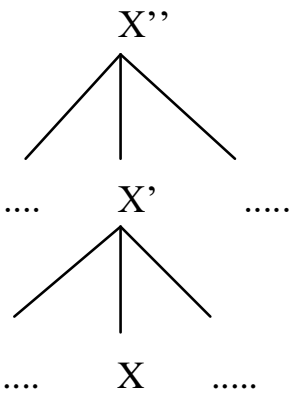

Dari gambar di aats dapat dilihat bahwa symbol $\mathrm{X}$ merupakan pengganti dari sebuah kategori leksikal seperti nomina, verba, preposisi maupun adjektiva dan tanda titik diisi oleh tiga fungis gramatikal yaitu komplemen, specifier, dan keterangan. Dalam bahasa Batak Toba komplemen dan keterangan cukup sulit untuk dibedakan.Komplemen adalah bentuk argument yang bersifat wajib dan harus ada serta posisinya langusng ebrada di bawah xbar sedangkan keterangan bersifat opsional dan posisinya dapat diletakkan sebelum atau sesudah inti kalimat. m sebelum atau sesudah inti kalimat.

Penelitian mengenai verba serial terhadap bahasa-bahasa nusantara telah banyak dilakukan baik menyangkut konstruksinya maupun berdasarkan tipe semantisnya. Misalnya, penelitian verba seria dalam bahasa Madura (Ummah, 2018), Bahasa Rongga (Kosmas, 2007) Bahasa Sunda (Muflikhatin, 2017), Bahasa Dawan (Benu, 2001),dan bahasa sasak (Pradnyayanti, 2010) namun peneliti tidak menemukan adanya penelitian mengenai verba serial dalam bahasa Batak Toba. Oleh karena itu , penelitian ini penting dilaksanakan untuk mendeskripsikan konstruksi verba serial dalam Bahasa Batak Toba sebagai upaya pelestarian bahasa nusantara Dalam penelitian ini akan dianalisis konstruksi verba serial dalam bahasa Batak Toba dengan menggunakan teori $\mathrm{x}$-bar.

\section{METODOLOGI PENELITIAN}

Penelitian ini merupakan penelitian kualitatif. Metode ini merupakan metode penelitian yang semata-mata hanya berdasarkan fakta atau fenomena yang memang secara empiris hidup pada penuturnya sehingga dihasilkan data apa adanya. (Sugiyono, 2016). Data penelitian diperoleh melalui wawancara langsung kepada penutur aslinya dan melalui teks almanak berbahasa Batak Toba. Alasan pemilihan teks almanak karena dalam teks tersebut terdapat wacana berisi khotbah, nasehat,instruksi dan informasi yang menggunakan Bahasa Batak Toba. Seluruh data diperoleh dengan mengginakan teknik simak catat. Selanjutnya data yang diperoleh dianalisis menggunakan teknik lesap, substitusi dan penyisipan. (Sudaryanto, 2015).

Adapun langkah penelitian dimulai dengan wawancara terhadap informan. Melalui wawancara diharapkan diperoleh data penggunaan verba serial dalam bahasa seharihari. Data yang diperoleh selanjutnya dikelompokkan berdasarkan jenis predikatnya apakah berbentuk transitif atau intransitif. Selanjutnya, data yang telah dikelompokkan dianalisis dengan menggunakan teori $\mathrm{x}$-bar.

\section{HASIL DAN PEMBAHASAN}

Hasil analisis menunjukkan bahwa pola pembentukan konstruksi verba serial dalam bahasa Batak Toba meliputi :

\section{Pola Pembentuk V1 intransitif + V2 Transitif}

Dalam bahasa Batak Toba, verba serial dapat dibentuk dengan pola V1 Transitif + V2 Transitif. Contoh kalimat yang dibentuk dengan pola ini dapat dilihat pada kalimat berikut :

(1) $\operatorname{Marsiajar}_{(\mathrm{v}}$ intransitif) mangaloppa (v transitif) loppan akka borua

Belajar memasak lauk-pauk para perempuan

'belajar memasak lauk pauk para perempuan'

Bentuk verba serial dalam kalimat di atas adalah marsiajar mangaloppa. Dalam kalimat (1) verba marsiajar mangaloppa berfungsi sebagai predikat tunggal dan tidak dapat dipisahkan ataupun diubah letaknya. Apabila letaknya berubah maka makna 
kalimatnya pun akan berubah dan menimbulkan makna yang ambigu. Hal ini dapat dibuktikan dengan menggunakan teknik balik berikut :

(1a) mangaloppa marsiajar loppan akka borua Memasak belajar laukpauk anak perempuan

Kalimat (1a) tidak berterima secara sintaksis dan bermakna ambigu. Jadi, verba marsiajar mangaloppa tidak dapat dipisahkan dan membentuk klausa tunggal, sehingga dapat dikategorikan sebagai bentuk verba serial.

Adapun konstruksi verba serial di atas yakni V1 marsiajar yang merupakan verba transitif karena membutuhkan objek dan V2 adalah mangaloppa yang merupakan verba transitif juga membutuhkan objek. Hal ini dapat dibuktikan dalam kalimat berikut:

(1b) $\operatorname{marsiajar}_{(\mathrm{V} \text { transitif) }}$ ende koor akka borua belajar lagu koor para wanita ' belajar nyanyian koor para wanita'

(1c) mangaloppa (Vtransitif loppan akka anak boru

memasak lauk pauk para wanita 'memasak laukpauk para wanita'

Kata marsiajar pada kalimat (1b) merupakan verba transitif karena harus diikuti oleh objek. Demikian juga magaloppa pada kalimat (1c) harus membutuhkan diikuti oleh objek. Berikut struktur KVS kalimat (1) di atas:

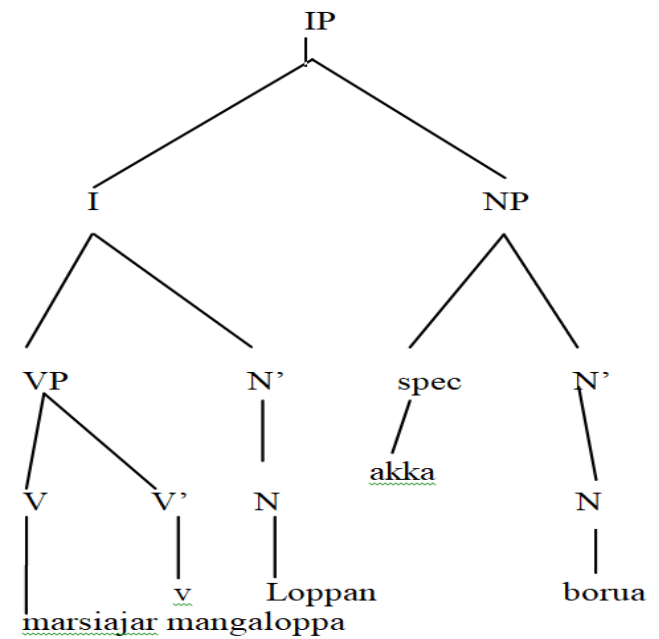

2.Pola pembentukan V1 Transitif + V2 Intransitif

Dalam bahasa Batak Toba, verba serial juga dapat dibentuk dengan pola V1 transitif + V2 Intransitif. Contoh kalimat yang dibentuk dengan pola ini dapat dilihat pada kalimat berikut ini :

(2) Manggora (v trans) $\mathrm{ro}_{(\mathrm{v} \text { intans })}$ pandita $\mathrm{i}$ memanggil datang (jemaat) pendeta itu

'memanggil datang (jemaat) pendeta itu'

Bentuk verba serial dalam kalimat di atas adalah manggora ro. . Dalam kalimat (2) di atas konstruksi verba manggora ro tidak dapat dipisahkan dan diubah letaknya. Apabila letaknya diubah, maka akan mengubah makna kalimat. Verba manggora ro berfungsi sebagai predikat tunggal. Hal ini dapat dibuktikan dengan teknik balik pada kalimat berikut :

(2a) ro manggora pandita i

datang memanggil (jemaat) pendeta itu

'datang memanggil (jemaat) pendeta itu'

Kalimat (2a) memiliki makna yang berbeda jika dibandingkan dengan kalimat (2) .Verba ro manggora pada kalimat (2a) bermakna bahwa pendeta datang memanggil sedangkan manggora ro pada kalimat (2) bermakna pendeta memanggil jemaat supaya datang. Jadi, manggora ro merupakan bentuk verba serial. Apabila KVS menunjukkan sebab akibat, maka konstruksi akan didahulu verba sebab mendahului verba akibat ( Haspelmath, 2016)

Verba manggora dalam kalimat (2) merupakan verba transitif karena membutuhkan dua argumen, sedangkan ro merupakan verba intransitif. Hal ini dapat dibuktikan dalam kalimat :

(2b) manggora ${ }_{(v \text { trans }}$ akka ruas pandita $\mathrm{i}$

Memanggil jemaat lah pendeta itu

'memanggil jemaat lah pendeta itu'

(2c) $\mathrm{ro}_{\text {(v intransitif) }}$ ma pandita $\mathrm{i}$

Datang lah pendeta itu

'datanglah pendeta itu'

Pada kalimat (2b) dapat dilihat bahwa

verba manggora merupakan verba transitif karena diikuti oleh kata ruas yang berfungsi

Pola Pembentukan Kontruksi Verba Serial dalam Bahasa Batak Toba (Teori X-Bar) 
sebagai objek , sedangkan dalam kalimat (2c) verba ro merupakan verba intransitif karena tidak diikuti oleh objek.

Berikut struktur KVS kalimat (2) di atas :

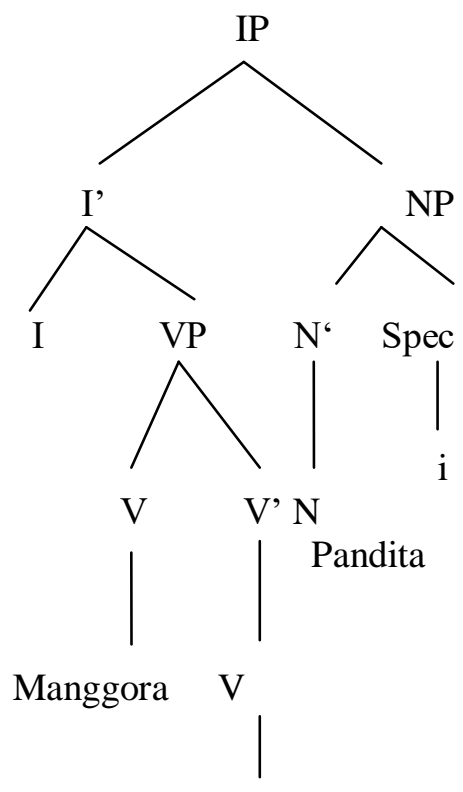

ro

\section{Pola pembentukan V1 Intransitif + V2 Transitif}

Hasil analisis menunjukkan ditemukan pola pembentukan KVS dengan pola V1 Intransitif + V2 Transitif. Bentuk ini merupakan bentuk yang paling umum ditemukan dalam bahasa Batak Toba. Berikut contoh kalimatnya :

(3) $\operatorname{lao}_{(\mathrm{v} \text { intrans) }} \operatorname{mamboan}_{(\mathrm{v} \text { trans) }}$ inangna si Poltak tu gareja.

Pergi membawa ibunya si Poltak ke gereja

'pergi membawa ibunya si Poltak ke gereja'

Bentuk lao mamboan merupakan verba serial karena tidak dapat dipisahkan dan diubah letaknya. Apabila letaknya diubah, maka kalimat tersebut tidak berterima secara sintaksis dan mengakibatkan keambiguan makna kalimat. Dalam hal ini verba lao mamboan berfungsi sebagai predikat tunggal. Hal ini dapat dibuktikan dengan teknik balik pada kalimat berikut :

(3a) mamboan lao inangna si Poltak tu gareja

Membawa pergi ibunya si Poltak ke gereja 'membawa pergi ibunya si poltak ke gereja,

Kalimat (3a) di atas tidak berterima karena kadar kepositifan antara V1 dan V2 rendah akibat perubahan letaknya. Selain itu, jika kedua verba tersebut dibalik posisinya maka makna kalimat tersebut tidak berterima karena menimbulkan makna yang ambigu.

Bentuk verba serial lao mamboan dalam kalimat (3) berpola V1 Intransitif + V2 transitif. Pola pembentukan V1 adalah lao yang merupakan verba intransitif dan V2 adalah mamboan yang merupakan verba transitif. Pada kalimat (3) di atas, pembentukan verba lao membutuhkan satu argumen yang berfungsi sebagai subjek sedangkan verba mamboan membutuhkan dua argumen yakni sebagai subjek dan objek . Konstruksi yang dimaksud dapat dibuktikan dengan kalimat berikut:

(3b) lao tu gareja si Poltak Pergi ke gereja Si poltak 'pergi ke gereja si Poltak'

(3c) mamboan inangna si Poltak tu gareja membawa ibunya si Poltak ke gereja 'membawa ibunya si Poltak ke gerej'

Pada kalimat (3b) verba lao hanya membutuhkan satu argumen yaitu si Poltak yang berfungsi sebagai subjek. Sedangkan dalam kalimat (3c) verba mamboan membutuhkan dua argumen yakni si Poltak yang berfungsi sebagai asubjek dan inangna sebagai objek.

Berikut konstruksi KVS dari kalimat (3) tersebut

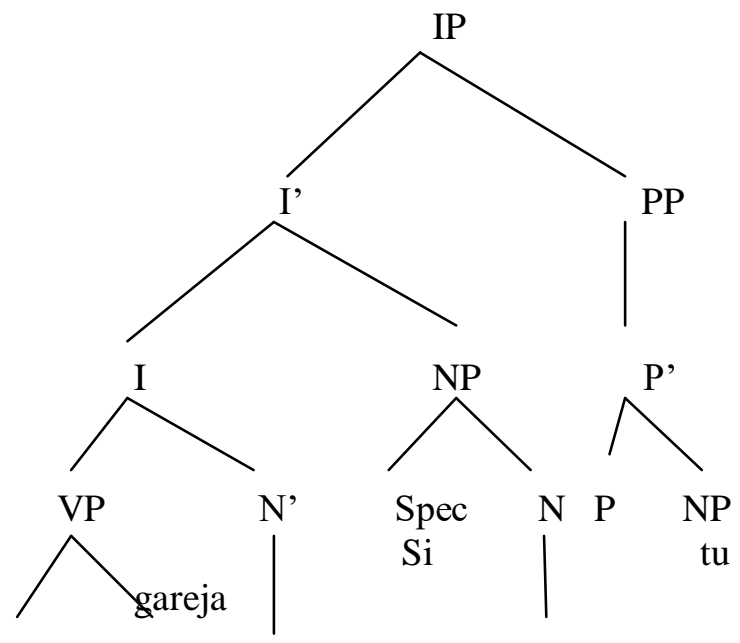

Pola Pembentukan Kontruksi Verba Serial dalam Bahasa Batak Toba (Teori X-Bar) 


$\left.\left.\right|_{\text {lao }}\right|_{\text {mamboan }} ^{\mathrm{V}}$ Inangna poltak

\section{Pola pembentukan V1 Intransitif + V2 Intransitif}

Dalam bahasa Batak Toba, verba serial juga dapat dibentuk dengan pola V1 intransitif + V2 Intransitif. Konstruksi ini dapat dilihat dalam kalimat berikut:

(4) $\operatorname{marlao}_{(\mathrm{v} \text { intarns) }} \mathrm{ro}_{(\mathrm{v} \text { intrans) }}$ akka jolma tu jabuna

pergi datang banyak orang ke rumahnya

'datang dan pergi orang-orang ke rumahnya'

Bentuk marlao ro pada kalimat (4) di atas merupakan verba serial karena tidak dapat dipisahkan dan dipertokarkan posisinya. Apabila letaknya diubah, maka kalimat tersebut tidak gramatikal sehingga tidak berterima secara sintaksis. Hal ini dapat dibuktikan dengan teknik balik berikut :

(4a) ro marlao akka jolma tu jabuna

Datang pergi banyak orang ke rumah nya

Kalimat di atas tidak gramatikal akibat adanya perubahan posisi marlao ro menjadi ro marlao. Bentuk ro marlao tidak berterima sehingga kalimat tersebut tidak berterima secara sintaksis. Marlao ro pada kalimat di atas berfungsi sebagai predikat tunggal.Jadi, bentuk tersebut dapat dikategorikan sebagai verba serial.

Pola pembentukan verba lao ro terdiri dari V1 Intransitif + V2 Intransitif. Lao merupakan verba intransitif yang hanya memerlukan satu argumen yakni sebagai subjek saja. Demikian juga verba ro hanya membutuhkan satu argumen yang bertindak sebagai subjek. Berikut pembuktiannya :

(4b) lao ibana tu juma

Pergi dia ke ladang

'pergi dia ke ladang' (4c) ro ibana sian juma

Datang dia dari ladang

'datang dia dari ladang'

Pada kalimat (4b) dan (4c) dapat dilihat bahwa verba lao dan ro hanya membutuhkan satu argumen yaitu kata ibana yang berfungsi sebagai subjek.

Berikut Konstruksi KVS dari kalimat (4) tersebut :

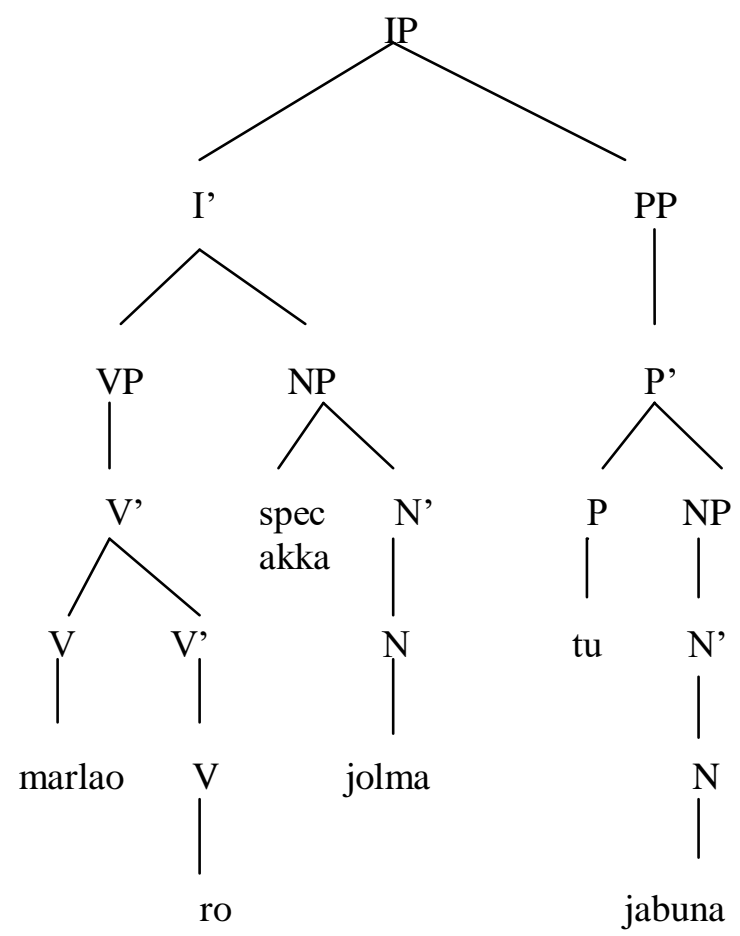

\section{SIMPULAN}

Berdasarkan hasil penelitian dapat disimpulkan bahwa konstruksi verba serial bahasa Batak Toba terdiri atas empat pola yaitu [transitif V1+ transitif V2], [transitif $\mathrm{V} 1+$ intransitif $\mathrm{V} 2$ ], [intransitif $\mathrm{V} 1+$ transitif $\mathrm{V} 2$ ], [intransitif $\mathrm{V} 1$ + intransitif V2]. Verba serial bertipe [transitif $\mathrm{V} 1+$ transitif V2] terbentuk dari predikat yang diikuti oleh objek + predikat yang diikuti oleh objek. Verba serial bertipe [V1 transitif + V2 intransitif] terbentuk dari predikat yang diikuti oleh objek + predikat yang tidak diikuti oleh objek. Verba serial bertipe [V1 intransitif + V2 transitif] terbentuk dari predikat yang tidak diikuti oleh objek + predikat yang diikuti oleh objek. Verba serial bertipe [V1 intransitif + V2 intranstif] terbentuk dari predikat yang 
tidak diikuti oleh objek + predikat yang tidak diikuti oleh objek.

\section{REFERENSI}

Aikhenvald. Y Alexandra. (2006). Serial Verb Construcsion. Oxford University NewYork.

Asnawi, A., \& Mukhlis, M. (2019). Perilaku Sintaksis Verba Bahasa Banjar Hulu: Tinjauan Fungsi Gramatikal. GERAM (Gerakan Aktif Menulis), 7(2), 83-95. https://doi.org/10.25299/geram.2019.vol7 (2). 3777

Benu, N. N. (2001). Konstruksi Verba Serial Bahasa Dawan. Udayana University Denpasar.

Durie, M. (1997). Verb Serialization and verbal Preposition. Oceanic Linguistics, Vol 27, 1-23., Volume 27, 1-23.

Givon, T. (1984). Syntax: An Introduction Volume 1. Netherlands: John Benjamins Publishing Amsterdam.

Haspelmath, M. (2016). The serial Verb Construction: Comprative Concept and Cross-Linguistic Generalizations. Sage Journal.

Kosmas, J. (2007). Konstruksi Verba Serial Bahasa Rongga. Jurnal Unud.

Kroeger, P. R. (2004). Analyzing syntax: A lexical-Functional Approac. Cambridge: Cambridge University Press.

Muflikhatin, I. (2017). Konstruksi Verba Serial Tipe Gerakan Dalam Bahasa Sunda: kajian Tipologi dan X Bar. Universitas Diponegoro.

Mulyadi. (2010). Frase Preposisi Bahasa Indonesia : Analisis X Bar. Jurnal Kajian Sastra.

Pradnyayanti, L. P. A. (2010). "Konstruksi Verba Beruntun Bahasa Sasak Dialek Ngeto-Ngete." Udayana University.

Sibarani, R. (1997). Sintaksis Bahasa Batak Toba. Medan Sumatera Utara: USU Press.

Sudaryanto. (2015). Metode dan aneka teknik analisis bahasa: Pengantar Penelitian dan Wahana Kebudayaan Secara Linguistis. Duta Wacana University Press.

Sugiyono. (2016). Memahami Penelitian Kualitatif. Bandung: Alfabeta.
Ummah, K. (2018). Pola Pembentukan KonstruksiVerba Serial Bahasa Madura dan Struktur Konstituen (Kajian Tipologi Bahasa dan Struktur Konstituen Teori X Bar). Prosiding Riksa Bahasa XII Universitas Pendidikan Indonesia.

Verhaar, J. W. M. (2001). Asas-Asas Linguistik Umum. Yogyakarta: Gajah Mada University Press.

Pola Pembentukan Kontruksi Verba Serial dalam Bahasa Batak Toba (Teori X-Bar) 